Article

\title{
Surpassing the Line: Urban-Oriented Strategies in the Development of Business Complexes in Poland
}

\author{
Piotr Lorens *, Joanna Bach-Głowińska, Michał Habier and Paweł Rzepecki \\ Department of Urban Design and Regional Planning, Faculty of Architecture, Gdańsk University of Technology, Poland; \\ E-Mails: piotr.lorens@pg.edu.pl (P.L.), joanna.glowinska@pg.edu.pl (J.B.-G.), michal.habier@pg.edu.pl (M.H.), \\ rp.rzepecki@gmail.com (P.R.) \\ * Corresponding author
}

Submitted: 8 March 2021 | Accepted: 20 May 2021 | Published: 23 September 2021

\begin{abstract}
Development trends regarding the business-related urban complexes seem to evolve from the "big-box" towards the more "multi-use" types of structures. Within it, the special role is reserved for places, which-due to economic, political, and geographical reasons-have not been previously considered as major business hubs. Only recently, places like cities in Central and Eastern Europe have become attractive locations for business complexes. These could offer centrally located and attractive locations for new structures, which resulted in the development of the new type of commercial centers-in the form of multi-use districts, walkable, and complemented by other uses. Therefore, to some extent, these cities "surpassed the development line" of the commercial and business complexes, and have become home to something much more advanced. Within the article, the cases from Poland, including Gdańsk, Warsaw, Cracow, and Wrocław, are discussed. Not only is the urban arrangement of selected complexes presented, but the planning and socio-economic, legal, and infrastructural aspects of these developments are also discussed.
\end{abstract}

\section{Keywords}

business centers; Cracow; Gdańsk; multi-use projects; Warsaw; Wrocław

\section{Issue}

This article is part of the issue "Future Commercial and Industrial Areas" edited by Angela Million (TU Berlin, Germany) and Felix Bentlin (TU Berlin, Germany).

(C) 2021 by the authors; licensee Cogitatio (Lisbon, Portugal). This article is licensed under a Creative Commons Attribution 4.0 International License (CC BY).

\section{Introduction}

The office clusters-and office-dominated business parks and complexes-became increasingly common across Europe in the second part of the 20th century. This trend emerged as a result of the Western European shift from industrial to service-based economies (Barnett \& Parnell, 2018). The other pragmatic issue was that in the city's dense office structure, the centralized infrastructure systems were far more efficient while serving the multiple buildings located close to each other (Gang et al., 2016). As a result, the concept of the central business district (CBD) emerged. In many cases it was associated with the downtown areas; however, the term was sometimes applied to the central cities of the metropoli- tan area, namely "core" and "urban core." The "core" was conceptualized and outlined by its position on the mental map of the inhabitants. CBD was originally seen as a somewhat distinctive area. As for its original character, the CBD was easily accessible, with a greater concentration of tall buildings than anywhere else in the city, with the largest retail and commercial facilities. CBD was widely known for its congested and overcrowded streets. Land values within these areas were higher than average elsewhere (Murphy, 2017).

The extended set of location criteria match the decision makers' preferences well while selected according to the individual valorization and assessment hierarchy. Thus, the exemplary list of the location variables for evaluating the location of the CBD proposals in 1st, 2nd tier, 
and 3rd tier cities can be presented. The authors developed their analysis of these factors (see Table 1).

The concentration of economic activity around the most valuable areas in an undefined metropolitan core resulted in a vertical zoning characteristic of CBD. Throughout the time, the $\mathrm{CBD}$, originally dominated by offices and retail stores, was replaced by the accompanying set of specific functions within the CBD (hotels,

Table 1. Variables for evaluating location factors of CBD in 1st, 2nd, and 3rd tier cities.

\begin{tabular}{|c|c|c|c|}
\hline Variables & $\begin{array}{l}\text { CBD in 1st tier cities (in case of } \\
\text { Poland: a capital city) }\end{array}$ & CBD in 2nd tier cities & CBD in 3rd tier cities \\
\hline Cost & $\begin{array}{l}\text { Construction, taxes, utilities, } \\
\text { investment incentives }\end{array}$ & $\begin{array}{l}\text { Construction, taxes, utilities, } \\
\text { investment incentives }\end{array}$ & $\begin{array}{l}\text { Construction, taxes, utilities, } \\
\text { investment incentives }\end{array}$ \\
\hline \multirow[t]{2}{*}{ Location } & $\begin{array}{l}\text { Headquarters, large corporations } \\
\text { (finance, real estate and } \\
\text { insurance sector [FIRE]), critical } \\
\text { mass of similar firms, } \\
\text { contractibility distance to other } \\
\text { Alpha cities }\end{array}$ & $\begin{array}{l}\text { Large corporations } \\
\text { (FIRE/subsidiary), critical mass of } \\
\text { similar firms, contractibility } \\
\text { distance to the European metro } \\
\text { network }\end{array}$ & $\begin{array}{l}\text { Large corporations (subsidiary), } \\
\text { critical mass of similar firms, } \\
\text { contractibility distance to the } \\
\text { capital city }\end{array}$ \\
\hline & Nice and safe surroundings & $\begin{array}{l}\text { Quiet, safe, and nice } \\
\text { surroundings }\end{array}$ & $\begin{array}{l}\text { Quiet, safe, and nice } \\
\text { surroundings }\end{array}$ \\
\hline \multirow[t]{2}{*}{ Proximity } & $\begin{array}{l}\text { City center (core), prestigious } \\
\text { location, airport }\end{array}$ & $\begin{array}{l}\text { City center, train, metro, subway } \\
\text { station, motorway, airport }\end{array}$ & $\begin{array}{l}\text { City center, airport, train station, } \\
\text { by-pass motorway, subway, } \\
\text { seaport }\end{array}$ \\
\hline & $\begin{array}{l}\text { Clients, business partners, } \\
\text { suppliers }\end{array}$ & $\begin{array}{l}\text { Clients, suppliers, business } \\
\text { partners, universities }\end{array}$ & $\begin{array}{l}\text { Clients, suppliers, business } \\
\text { partners, universities }\end{array}$ \\
\hline \multirow[t]{3}{*}{ Access } & Public transport & Public transport & Public transport \\
\hline & $\begin{array}{l}\text { Complimentary business services, } \\
\text { culture, entertainment }\end{array}$ & $\begin{array}{l}\text { Complimentary business services, } \\
\text { retail, restaurants }\end{array}$ & Complimentary business services \\
\hline & $\begin{array}{l}\text { Distribution channels and } \\
\text { high-quality information network }\end{array}$ & $\begin{array}{l}\text { Distribution channels and } \\
\text { high-quality information network }\end{array}$ & $\begin{array}{l}\text { Distribution channels and } \\
\text { high-quality information network }\end{array}$ \\
\hline Car mobility & $\begin{array}{l}\text { Car access, parking available for } \\
\text { employees/clients }\end{array}$ & $\begin{array}{l}\text { Car access, parking available for } \\
\text { employees/clients }\end{array}$ & $\begin{array}{l}\text { Car access, parking available for } \\
\text { employees/clients }\end{array}$ \\
\hline \multirow[t]{3}{*}{ Availability } & R\&D knowledge & Industry cluster & Industry cluster \\
\hline & Distant markets & Lack of competitors & $\begin{array}{l}\text { Office space expansion } \\
\text { opportunity }\end{array}$ \\
\hline & $\begin{array}{l}\text { Sport/cultural amenities and } \\
\text { medical services, colleges, } \\
\text { universities, recreational } \\
\text { facilities }\end{array}$ & $\begin{array}{l}\text { Sport/cultural amenities and } \\
\text { medical services, colleges, } \\
\text { universities, recreational facilities }\end{array}$ & $\begin{array}{l}\text { Sport/cultural amenities and } \\
\text { medical services, colleges, } \\
\text { universities, recreational facilities }\end{array}$ \\
\hline \multirow[t]{2}{*}{ Resources } & $\begin{array}{l}\text { State regulatory environment, } \\
\text { the quality of the infrastructure }\end{array}$ & High-quality infrastructure & High-quality infrastructure \\
\hline & $\begin{array}{l}\text { Skilled with knowledge of foreign } \\
\text { languages, with market } \\
\text { experience }\end{array}$ & $\begin{array}{l}\text { Education level of residents, } \\
\text { skilled with knowledge of foreign } \\
\text { languages }\end{array}$ & $\begin{array}{l}\text { Education level of residents, } \\
\text { skilled with knowledge of foreign } \\
\text { languages }\end{array}$ \\
\hline Brand & $\begin{array}{l}\text { Municipal reputation as a good } \\
\text { place to work, prestigious } \\
\text { location in the capital city }\end{array}$ & $\begin{array}{l}\text { Municipal reputation as a good } \\
\text { place to live and work, } \\
\text { attractiveness of the area, unique } \\
\text { amenities, and venues }\end{array}$ & $\begin{array}{l}\text { Municipal reputation as a } \\
\text { high-quality place to live and } \\
\text { work, high attractiveness of the } \\
\text { area, alternative urban lifestyles } \\
\text { and vibrancy, unique amenities, } \\
\text { and venues }\end{array}$ \\
\hline
\end{tabular}

Source: Own study based on Karakaya and Canel (1998), Kimelberg and Williams (2013), and Smętkowski et al. (2021). 
restaurants, theatres, banks, nightclubs) and resulted in a decline in the use of the "core" blend. This helped to sustain the life of the formerly office-dominated areas (Polese \& Chapain, 2000). Therefore, the trend of relocating the CBDs from the archetypal city centers to the most accessible city parts seemed to be the natural consequence in a globalized world. The CBD's (re)location due to accessibility reasons was especially likely to happen in waterfront cities causing even a shift in the meaning of centrality (Murphy, 2017). Nevertheless, all of these trends have been reflected in some kind of standardization of CBD concepts around the world.

Considering the decision-making processes on CBD's (re)location, three general approaches were distinguished globally: the neoclassical, the behavioral, and the institutional (Bagchi-Sen, 2001). The first assumes that the decision is based on cost minimization (Kimelberg, 2014). The second behavioral approach assumes that with a limited amount of information available, the only rational attempt is to balance the economic factors with the others. The institutional approach challenges previous paradigms, recognizing that the intangible social and cultural context which can be found in the spatial dimension is crucial for business success.

The tendency of (re)location of the CBD areas was reinforced with the emergence of the creative sector concept and understanding its role in the successful development. The so-called creative clusters and districts have risen (Carta, 2007; Florida, 2005). Although the theory of the creative class by Florida (2005) was recently criticized, the development of creative districts (as conceptualized by Landry, 2008) as a driver of urban development is continuously being advocated (Culver, 2017), along with understanding that start-up companies have the same (if not greater) importance for economic development as large corporations. This trend is also accompanied by the development of the "slow-life" and "worklife-balance" concepts, which have resulted so far in the re-appreciation of the traditional social networks and types of urban structures (Hatuka et al., 2018).

All these factors have contributed to redesigning the landscape of the business-oriented built environments. This change has also been strengthened by the policy of sustainable urban development calling for a more dense, multi-use type of development, less dependent on cars, and more blended with the traditional urban fabric (e.g., Bott et al., 2019; Haas, 2012; Meijer et al., 2010; Säynäjoki et al., 2014). This is a new approach to city planning in general, and in defining development projects in particular (Burdett \& Rode, 2018; Stangel, 2013). Secondly, the developers-feeling the changes in the market, which started to demand more diverse urban environments-decided to reshape their master plans (e.g., Bullivant, 2012; Firley \& Grön, 2013; Rudlin \& Hemani, 2019), as well as the scope and character of particular projects. As a result, the business parks and office centers are no longer constructed like a big box meant to work alone at the premises. Modern companies wanted their employees to feel at home, so they tried to create an attractive workplace regardless of $1 \mathrm{st}$, 2nd, or 3rd tier city locations. The best-known example of this trend is the Google headquarters in Mountain View, which offers unique architectural solutions, excellent restaurants with free food from around the world, basketball courts, sun loungers, and much more (Ferguson, 2005).

Within this article, the issue of the location of the new type of business centers is discussed, focusing on the tendency to develop these new types of centers without the "big box-looking" structures. This tendency is a characteristic of "emerging markets," like Central Europe in general, and Poland specifically. The analysis of the cases presented in the article can serve as the point of departure for further research on the evolution of the city core areas in Central Europe and elsewhere. The state of the research was blended in the text, and the theoretical background was presented in its introductory parts. On that basis, it was possible to define the case studies to be discussed and, as a result of this elaboration, to draw more general conclusions on the nature of the phenomenon.

\section{Situation of the Business Centers in the Case of Poland}

The evolution of the business-cluster creation described above globally reflects the situation based on highly developed countries (in Western Europe or North America). However, at the end of the 20th century, a new group of markets emerged-including the Central and Eastern European ones-which were previously (due to political reasons) excluded from the processes of globalization and free flow of capital and labor. These countries could offer new opportunities for the location of business headquarters, and local companies (including newly created and dynamically growing ones) appeared to require new office spaces. The special role in this process is reserved for Poland, the largest of the Central European countries, with a dynamically developing economy and decentralized spatial structure (Gelbuda et al., 2008; Luthans et al., 1995).

Since its inception in the 1990s, the Polish real estate market has had an attractive performance record (Colliers International, 2020). Following the perceived "distinct locational advantages" (McCartney, 2012), the first market chosen had been Warsaw-the capital of Poland with the headquarters of both the Polish companies and Polish branches of the international corporations located since the early 1990s. The second market was established in regional centers such as Cracow, Poznań, and Wrocław, forming the set of major business centers in Poland, although in the course of 2020s, the relatively high position of Poznan was overtaken by Gdańsk, which nowadays tends to become the 4 th strongest center of business activity in the country (Morawiecki, 2021). Although the office clusters were developed mostly according to the transit-oriented 
development schemes, car accessibility continued to be highly important for the workers. It was believed that increasing the density near clustering office buildings has "many tangible economic benefits, which are likely to fuel the economic performance in real estate" (Kołodziejczyk et al., 2021, p. 171). The large clusters of office developments were undertaken regardless of the possibility of a permanent imbalance caused by rapid growth (Brzezicka et al., 2018).

Today, the office space available in Poland is estimated to be 11 million $\mathrm{m}^{2}$ in total. As far as the overall tendency focusing on the qualitative changes is concerned, it is understood that not only as the demand for a higher level of competencies (including hybrid jobs) but also as the potential employees' demand for more attractive work conditions (including the quality of place). Therefore, the case studies had to be selected from the major business centers in tier 1 and tier 2 cities in Poland, based on the comparative study of the modern business services sector in 2020 (ABSL, 2020). The literature review was carried out to establish the theoretical framework as further guidelines for practice-oriented research focusing on the differences in the development of the 1st, 2nd, and 3rd tier of Polish agglomerations and setting the criteria of city selection. The overall methodology aimed to investigate the quality in the indicated key areas in Poland that enable interactions between the office real estate complex and the urban tissue (community and city) focusing on the critical attempt rather than on case study description. The empirical research methods were documentary studies on office real estate complexes and structured studies on the local context with direct observation of public spaces. Finally, the primary research led to the designation of four CBD locations, namely Gdańsk (2nd-3rd tier), Wrocław (2nd tier), Cracow (1st-2nd tier), and Warsaw (1st tier) for conducting the further study. One must note that none of these cities are of exceptional international importance, which applies also to the capital city of Warsaw (Parteka, 2008).

By 2020, there were plans to construct the office clusters of approximately $100 \mathrm{k}$ gross leasable area (GLA), twice as much as in Warsaw by that time (see Table 2). The expected 100 k GLA demand in each (Gdańsk, Wrocław, and Cracow) was twice as high as in the other Polish sub-centers (Poznań, Katowice, Lublin) since 2004 (Morawiecki, 2021). Unexpectedly, due to Covid-19, the trend of the office cluster's expansion to Polish subcenters reversed at the turn of 2020 .

As can be derived from Table 2, the largest office markets in $\mathbf{2 0 2 0}$ were located within four major Polish cities: Warsaw, Cracow, Wrocław, and Tricity (including Gdańsk, Sopot, and Gdynia). As a result, these four centers were

Table 2. The office market analysis in the capital city (Warsaw) and the selected sub-centers of Gdańsk, Cracow, and Wrocław.

\begin{tabular}{|c|c|c|c|c|}
\hline & $\begin{array}{l}\text { Warsaw } \\
\text { (CBD and } \mathrm{NCL} \text { ) }\end{array}$ & $\begin{array}{l}\text { Tricity } \\
\text { (Gdańsk, Sopot, and Gdynia) }\end{array}$ & Cracow & Wrocław \\
\hline Number of inhabitants (2020) & $1,702,139$ & 751,314 & 755,050 & 634,893 \\
\hline Number of students (2019) & 246,000 & 120,000 & 148,300 & 120,000 \\
\hline Unemployment rate (\%) in 2019 and 2021 & $\begin{array}{l}1.4 \\
1.9\end{array}$ & $\begin{array}{l}2.3 \\
3.2\end{array}$ & $\begin{array}{l}2.3 \\
3.2\end{array}$ & $\begin{array}{l}1.7 \\
2.5\end{array}$ \\
\hline Medium salary (euro/month) & 1,486 & 1,202 & 1,322 & 1,272 \\
\hline GLA (sqm) 3rd quarter of 2020 & $\begin{array}{l}\text { (CBD) 2,387,514 } \\
\text { (NCL) 3,434,839 }\end{array}$ & 898,804 & $1,521,429$ & $1,235,004$ \\
\hline GLA supply (sqm) 3Q2020 & $\begin{array}{l}\text { (CBD) } 112,987 \\
\text { (NCL) } 18,488\end{array}$ & 30,360 & 38,160 & 48,941 \\
\hline GLA demand (sqm) 3Q2020 & $\begin{array}{l}\text { (CBD) } 288,608 \\
\text { (NCL) 4,876 }\end{array}$ & $-1,782$ & 13,828 & 5,164 \\
\hline Rent (euro/sqm/month) 3Q2020 & $\begin{array}{l}\text { (CBD) } 17.00 \\
(\mathrm{NCL}) 12.00\end{array}$ & 14.00 & 13.80 & 13.50 \\
\hline Rent dynamics (2019-2020; \%) & $\begin{array}{l}\text { (CBD) } 7.89 \\
(\mathrm{NCL}) 7.69\end{array}$ & -3.45 & -2.82 & 0.00 \\
\hline Vacancy rate (\%) 3Q2020 & $\begin{array}{l}\text { (CBD) } 8.42 \\
\text { (NCL) } 10.43\end{array}$ & 9.42 & 12.41 & 14.29 \\
\hline
\end{tabular}

Notes: (1) The CBD is limited by the Vistula, Trasa Łazienkowska, Raszyńska, and Towarowa streets, and the WZ route, according to Polish Office Research Forum (2017); (2) NCL stands for non-central area, according to Polish Office Research Forum, constituting the rest of Warsaw without the CBD; (3) the vacancy rate is a percentage of a building's GLA that is unoccupied by tenants. Source: Own study based on data by Colliers International (2020), Statistics Poland (2021), Polish Office Market (2019), and Morawiecki (2021). 
selected for further research. As far as the CBDs construction at the major regional centers in Poland is concerned, the high-density office complexes are built according to the new standards, i.e., not only the "big box" type of structures, but also "multi-use, clustered" types. This was due to several reasons, among which one should mention the availability of distressed and brownfield urban areas, the low density of central parts of the cities, as well as the willingness of local governments to develop high-quality urban environments (Ossowicz, 2019). It was also noticed that the clustered development should result in less energy consumption, less pollution, and, in consequence, higher users' satisfaction, enabling users to enjoy the amenities which accompany office real estate (Tapsuwan et al., 2018). Furthermore, it was also noticed that denser built environments foster social contacts and motivate interactions (Patacchini et al., 2015), which has become an important feature of the work environment for many employees, especially at the end of the 2010s.

\section{Description of the Key Case Studies}

Within each of the above-mentioned cities, the key business complexes were identified based on the analysis of the urban structure of the city as well as on the authors' expertise on development processes occurring within these. On that basis, one exemplary case was picked from each of the cities and researched in detail. Each of the case studies was presented in a unified way, which relates both to the text-based descriptions, presentation on schemes showing both the city-wide and local contexts, as well as images presenting the key features of the sites (i.e., typical interior walkable spaces, green area connections, transportation connections, and with convenient access to other parts of the city.

\subsection{Warsaw: Targowa Street/Daszyńskiego Roundabout Complex}

Warsaw is the capital city of Poland and its main business hub. Traditionally, the country headquarters of various companies were located within the structure of the city, although after the political and economic transformation of the 1990s, new business hubs emerged (Smętkowski et al., 2019). One of them-also referred to as the Warsaw CBD area-is located within the area of the Daszyńskiego roundabout and along Targowa Street. One must note that this is not the only location of office complexes in Warsaw, as there are numerous complexes spread around the urban structure of the city, and each of these is different.

\subsubsection{Urban Setting of the Selected Case Study}

The city's CBD is located in close vicinity to the city center, near the central train station, and close to the Okęcie International Airport. Thanks to its location on the edge of the historic urban center, the complex is neighbored by extensive housing districts, both developed after the war-time destruction and newly constructed. The area is also well served by public transportation lines (underground train line, tram, and bus routes) and has a good connection to the commercial centers of the city. The recent and rapid development of the area, which utilized many empty and vacated (due to the restructuring of the industrial estates) plots, resulted in a patchworktype urban structure. The key features of the location of the discussed case are presented in Figure 1.

\subsubsection{Current State of the Area}

The landscape of the selected area is characterized by the modern design of the office buildings, in many cases blended with pre-1989 structures which include occasional remnants of the pre-war urban structure. New structures are also infilling the historic urban layout of the area. Since some of the projects located within it occupy larger sites, within their structures one can find green spaces which are usually publicly available. The most notable example is the Plac Europejski square, which is perceived as a privately-owned but high-quality public space. The character of the site's landscape is presented in Figure 2.

\subsubsection{Planning and Development Mode}

The character of the site was decided in the city's planning documents, the authors of which defined the area as "the site of representative character" (Office of the Capital City of Warsaw, 2018). It was also proposed to densify the area as well as to locate within its borders various commercial and public services. Particular buildings and complexes were developed according to regulations included within both the so-called local plans (City of Warsaw, 2021) as well as in the special-purpose planning permits. Although such a mode of planning for the site is not perceived as the most comprehensive and desired, the site's high level of attractiveness has resulted in the relatively high quality of the urban structure. The above-mentioned diversity in the process of developing the particular projects results in differentiated conditions imposed on particular developers and site owners. This situation is also, in many cases, used extensively by the developers to maximize the floor area and height of the proposed buildings. As a result, the urban structure of the area is very much architectonically and functionally diversified.

\subsubsection{Social and Infrastructural Aspects of Project Implementation}

Blending new office and commercial complex areas within the existing city structures contributes to the area's attractiveness. The special role in this process is played by large-scale public areas, provided by some of 

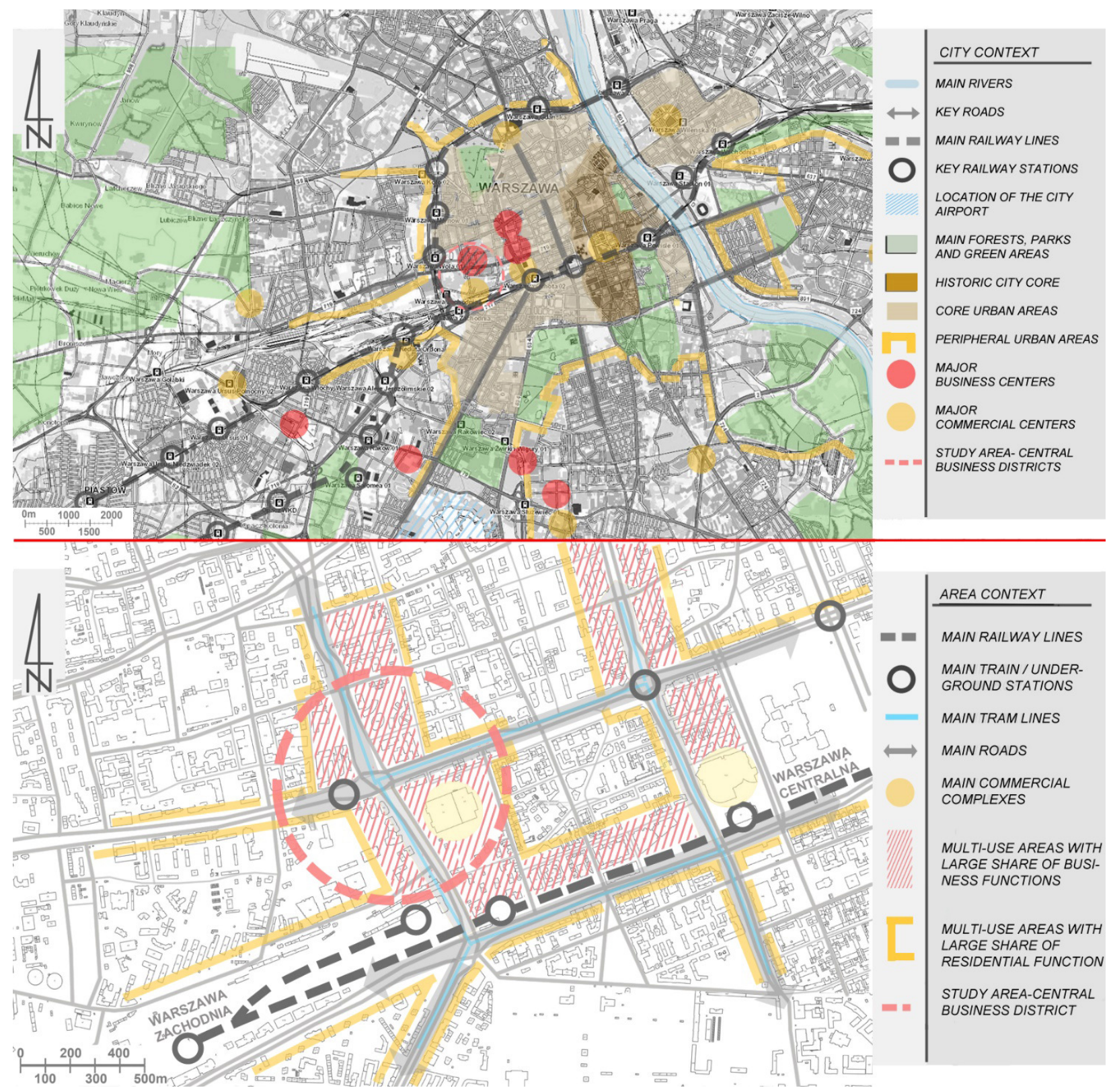

Figure 1. The urban setting of the Warsaw case study area.

the site developers. This large-scale area, known as Plac Europejski, was awarded a special prize by the Society of Polish Town Planners for the "best public space in Poland" in 2016. Also, the new housing estates emerged in close vicinity of the area, which contributed to the improvement of the housing offer within the entire city center. These estates took different forms, within which the traditional urban fabric with lots of accompanying commercial uses prevails. These attracted many new inhabitants, making the entire district a proper multi-use type of area, a true urban center of the growing metropolis.

\subsection{Cracow: Rondo Mogilskie/Rondo Grzegórzeckie}

Cracow is one of the oldest and best-preserved cities in Poland, a UNESCO cultural heritage site, and the second most important business hub in Poland. Many office com- plexes are scattered around the city. Rondo Mogilskie and Rondo Grzegórzeckie are the places around which the most notable structures were developed. Located in close vicinity of the Old Town, these pretend to become the proper CBD of the city.

\subsubsection{Urban Setting of the Selected Case Study}

The area is located in the vicinity of the Cracow main train station, which provides excellent connectivity with the airport and other cities both in the region and nationwide. The transportation infrastructure providing access to the area has been inherited from the previous era of planning and includes an extensive road network, which is presented in Figure 3. Also, the pedestrian connections were not given priority over car-related infrastructure. This resulted in the low quality of the urban environment, 


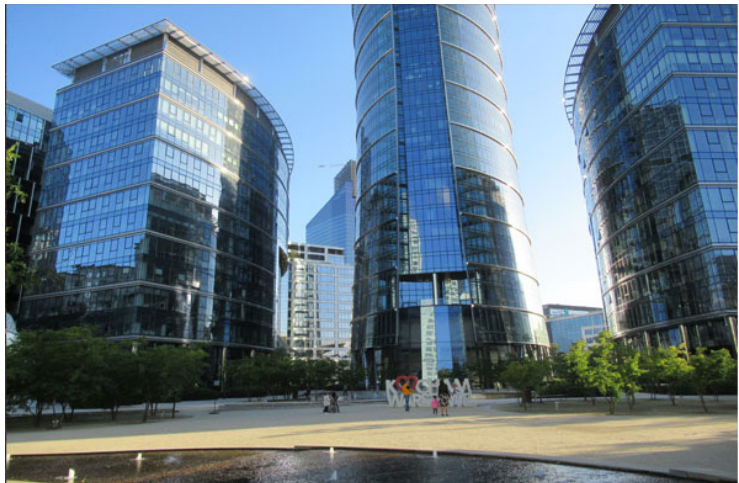

TYPICAL INTERIOR WALKABLE SPACE

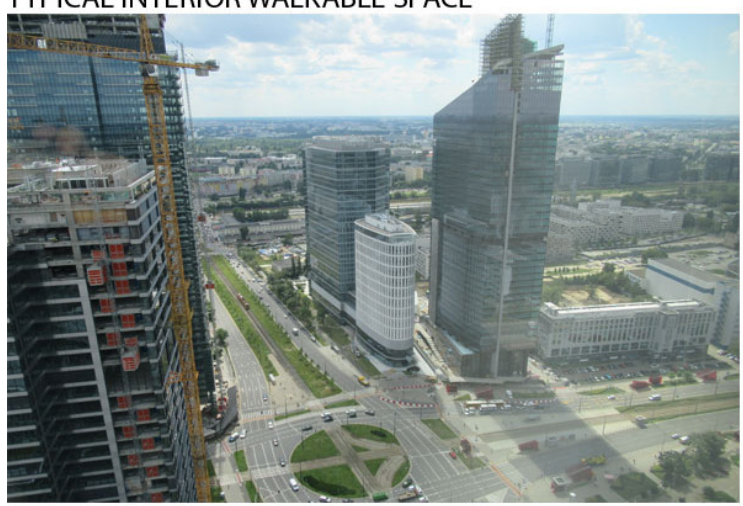

RAILTRACK AND STATION PASSING THROUGH

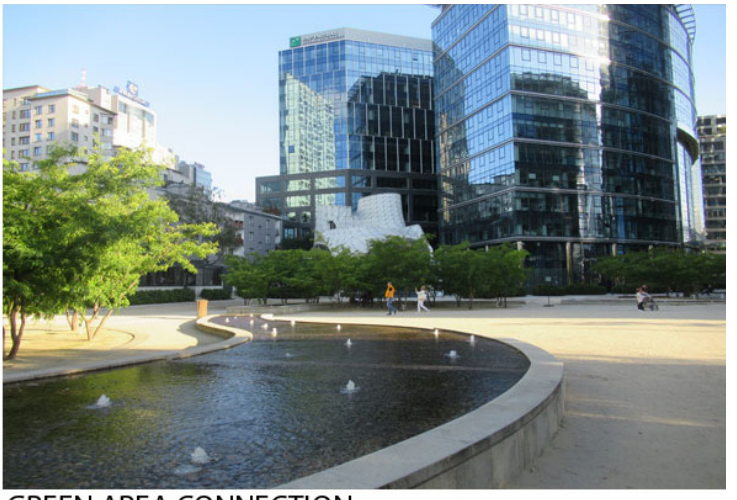

GREEN AREA CONNECTION

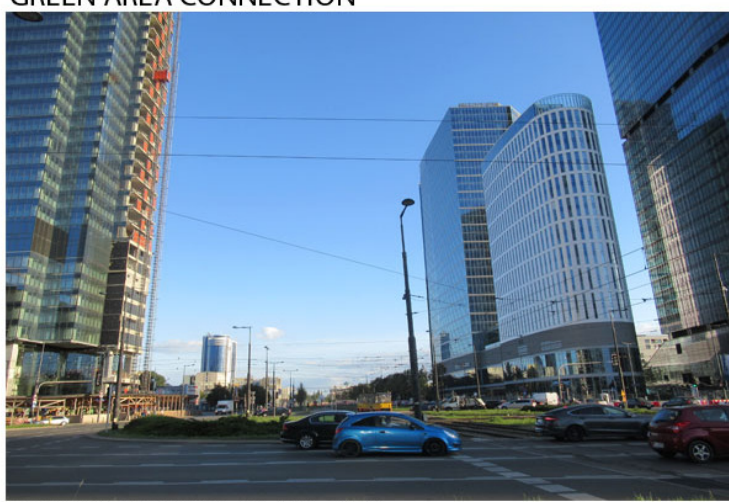

CONNECTION WITH THE CITY

Figure 2. The current state of the Warsaw case study area.

typical for the modernistic type of structure. Part of this is the tram network and recently added bike pathways system.

\subsubsection{Current State of the Area}

Currently, the site is being predominantly filled with new office buildings, which are also sporting the commercial infrastructure. These represent modern, though pretty standard architecture (see Figure 4). Nowadays in the vicinity of the two roundabouts, being the core of the road structure for the area, local multi-use centers are emerging, which also serve extensive housing structures located nearby.

\subsubsection{Planning and Development Mode}

Within the municipal master plan for the city of Cracow, the area in question was marked as the "main central area designated for the New Cracow City Center" (Public Information Bulletin of the City of Kraków, 2014). Most of the complexes and buildings are not built according to the well-defined planning regulations, as most of them are based on individually issued planning permits. This, confronted with the legacy of modernistic transportation planning, does not allow proper coordination of the area development (City of Kraków, 2021). The planning specifics of the area development result in a random location of the new office and public buildings within the area, resulting in great diversity, but, at the same time, little coordination and comprehensiveness.

\subsubsection{Social and Infrastructural Aspects of Project Implementation}

Development of the new office building complexes seems like an opportunity to break with the modernistic road layout of the district, within which it was located. This also helped in regenerating surrounding housing areas and improving commercial functions within them. Also, creating opportunities to work and live at a close distance contributes to the process of sustaining urban structures and improving the quality of life of the local community. At the same time, distribution of the office program among three major concentrations and locating it within the vicinity of two major commercial complexes as well as within walking distance of the Old Town and main train station complex helped to avoid the mono functionality of the area. Also, the location of these structures within walking distance from the city's main train station as well main lines of public transport (trams) provides excellent opportunities for workers, inhabitants, and visitors to the area to get there without the need of using a private car.

\subsection{Wrocław: Mikołajów}

Wrocław is a city which, in the last twenty years, has been to some extent reinvented as the major urban center in Poland. Being one of the major German cities before 


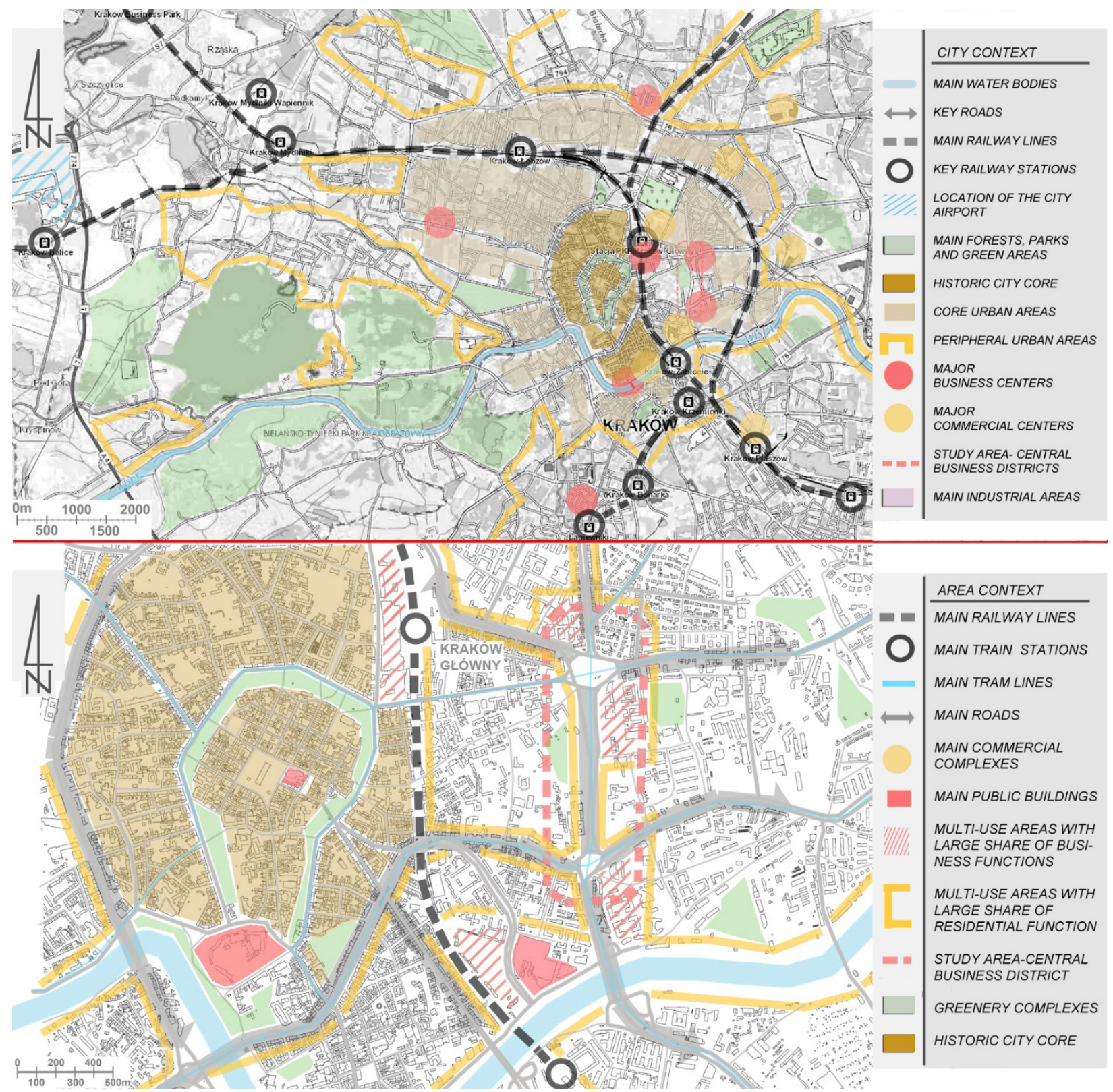

Figure 3. The urban setting of the Cracow case study area.

WWII, later on extensively destroyed by bombardments and the siege of the Red Army in 1945, it had struggled through the communist era with the provincial location. Only after the political changes of the 1990s did it go through an in-depth transformation into one of the most important Polish urban and business centers.

\subsubsection{Urban Setting of the Wrocław Case Study}

In the case of Wrocław, the Business Garden Office Park was selected. Located in the western part of the urban center, it is situated in close vicinity of the city's international airport and right next to Mikołajów train station. Also, numerous public transport lines allow smooth communication with the rest of the city. It also neighbors the large housing area as well as the commercial center (see
Figure 5). Nearby, one can also find a park that provides recreational opportunities for the office complex employees. However, the Business Garden Office Park, along with other neighboring sites, forms a rather isolated enclave.

\subsubsection{Current State of the Area}

The majority of the office park structure was developed according to a single architectural concept, which resulted in the unified architecture of the buildings that make it up. The aesthetics of the neighboring structures seem to follow the style defined by the design of the main part of the complex. The entire complex corresponds with the scale and form of the Wroclaw city architecture, which contributes to the image of the highquality urban environment of the area (Figure 6). 


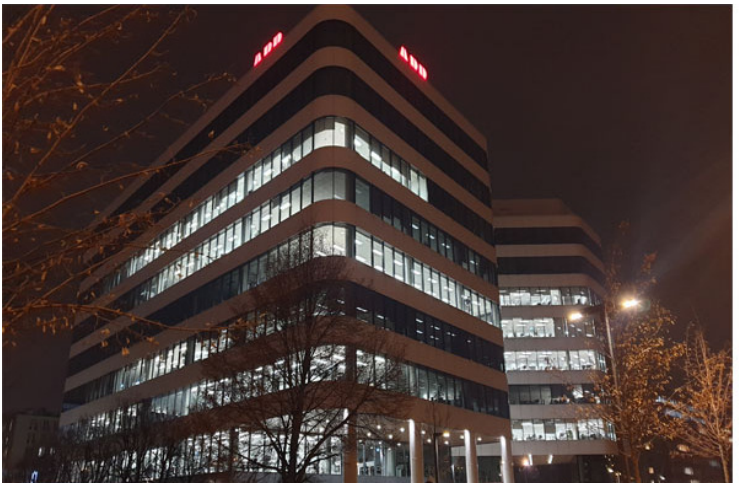

TYPICAL INTERIOR WALKABLE SPACE

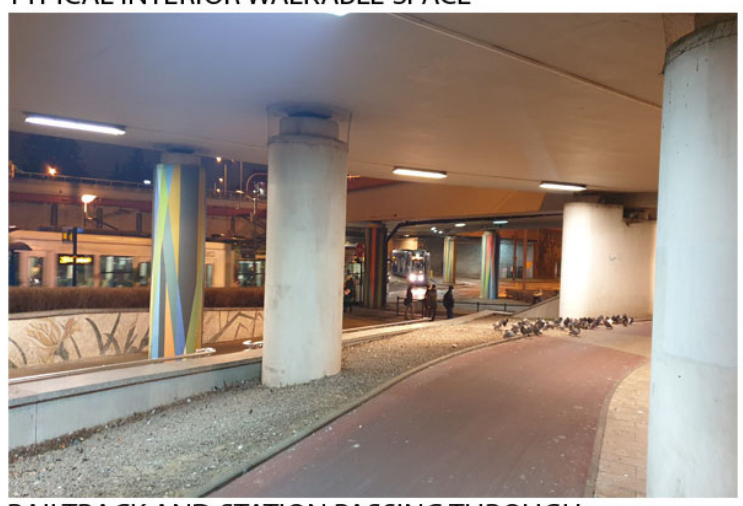

RAILTRACK AND STATION PASSING THROUGH

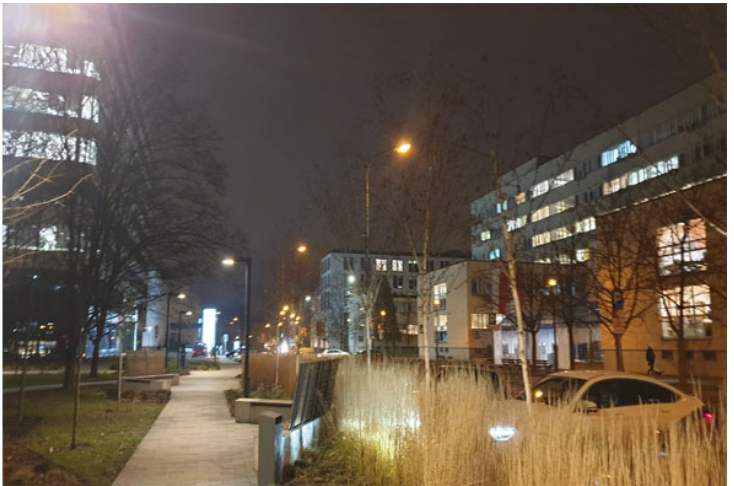

GREEN AREA CONNECTION

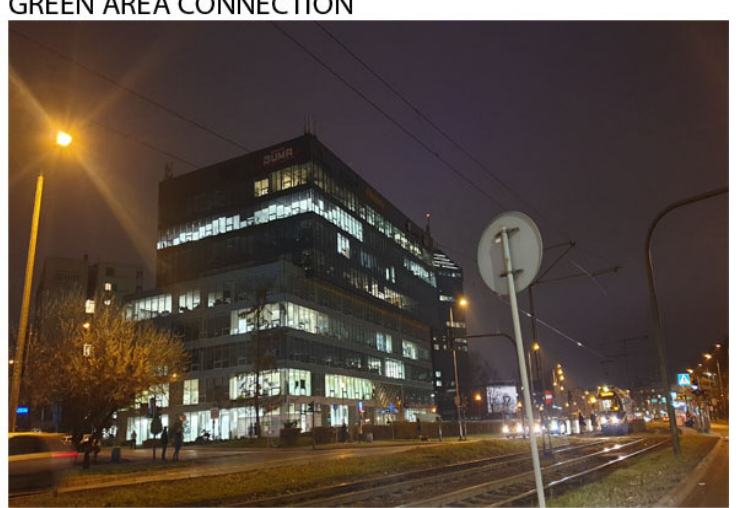

CONNECTION WITH THE CITY

Figure 4. The current state of the Cracow study area.

\subsubsection{Planning and Development Mode}

The area surrounding the Mikołajów train stationaccording to the Wrocław Development Plan-has been designated as one of the major concentrations of office and industrial complexes in the city (Wrocław Spatial Information System, 2021a, 2021b). Also, most of the study area has been covered by the development regulations included in the local planning documents, which, in principle, allows proper coordination of the area development (Wrocław Spatial Information System, 2021). According to these regulations, it seems possible to predict the future type of land use of the still developable areas as well as relations and connections between particular parts of the site. Besides, within these documents, the representative function of the main roads and public spaces has been declared, which also becomes a clear indication for the future transformations of these.

\subsubsection{Social and Infrastructural Aspects of Project Implementation}

Close to the city center, the inclusion of numerous commercial services in the urban program of the complex as well as excellent functional and transportation connections with the surrounding neighborhoods decide the attractiveness of the area. Nevertheless, many improvements still have to be made, mostly concerning the transformation of the main roads and the development of public space systems. One must point out the excellent transit opportunities for the inhabitants and workers from the area: The location of one of the city's main train stations in the center of the complex provides good access to other parts of Wrocław, as well as connections to the rest of the country. Also, the plots surrounding the office complex, although designated for housing, are still empty and await new developments. So, potentially, this entire complex may become an excellent example of a complete multi-use type of neighborhood, but for now, it still lacks many features.

\subsection{Gdańsk: Olivia Business Centre and Alchemia Complexes}

Gdańsk is one of the most historic cities in Poland, a major harbor, and tourist center. Along with Sopot and Gdynia, it forms the Tricity metropolis, which is the largest business hub in the northern part of the country. At the same time, its rich history-associated with the rise of the Solidarity movement as well as immense development during the Hanseatic times-along with outstanding environmental features (proximity to the sea and major forest complexes) make it a city of the highest living quality in Poland.

\subsubsection{Urban Setting of the Selected Case Study}

The area selected as a case study is located between the districts of Wrzeszcz and Oliwa, next to the regional train station Gdańsk-Przmorze-Uniwersytet. It has become a 


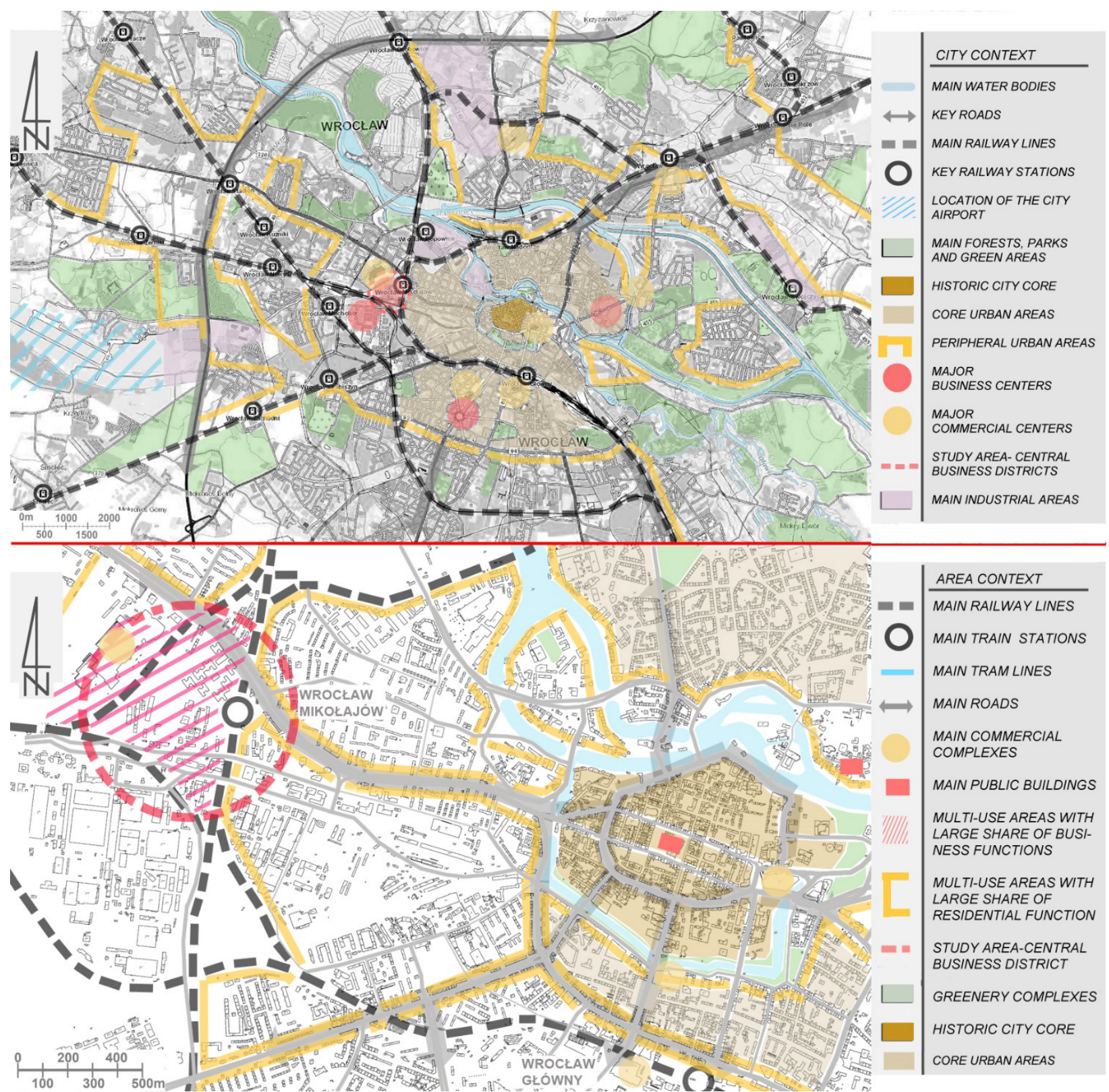

Figure 5. The urban setting of the Wrocław case study area.

home for at least three major office complexes-the main campus of the Olivia Business Centre, the Alchemia office complex, and the Skanska office complex. It neighbors with the Gdańsk University campus as well as the well-developed housing districts of Oliwa, Przymorze, and Zaspa. Also, many commercial facilities may be found in nearby areas (Figure 7).

\subsubsection{Current State of the Area}

At present, the office and business developments are concentrated around the three above-mentioned complexes. Each of these can be regarded as a large-scale urban intervention. The program of each of these is truly diverse and includes numerous commercial activities, a sports center, greenhouse-style enclosed public space, and top-notch restaurants and bars located on the top floors of the main office tower of the Olivia Business Centre complex (Figure 8).

\subsubsection{Planning and Development Mode}

According to the municipal development plan, the area in question was designated as one of the major parts of the so-called central commercial strip of the city (Portal of the City of Gdańsk, 2021). This resulted in the concentration of numerous and diverse functions, both within its structures as well as in other neighboring sites. The development potential of the area is additionally increased by the proximity of the Gdańsk University complex. Also, since the entire area has been included in the local planning regulations, all development activities- 

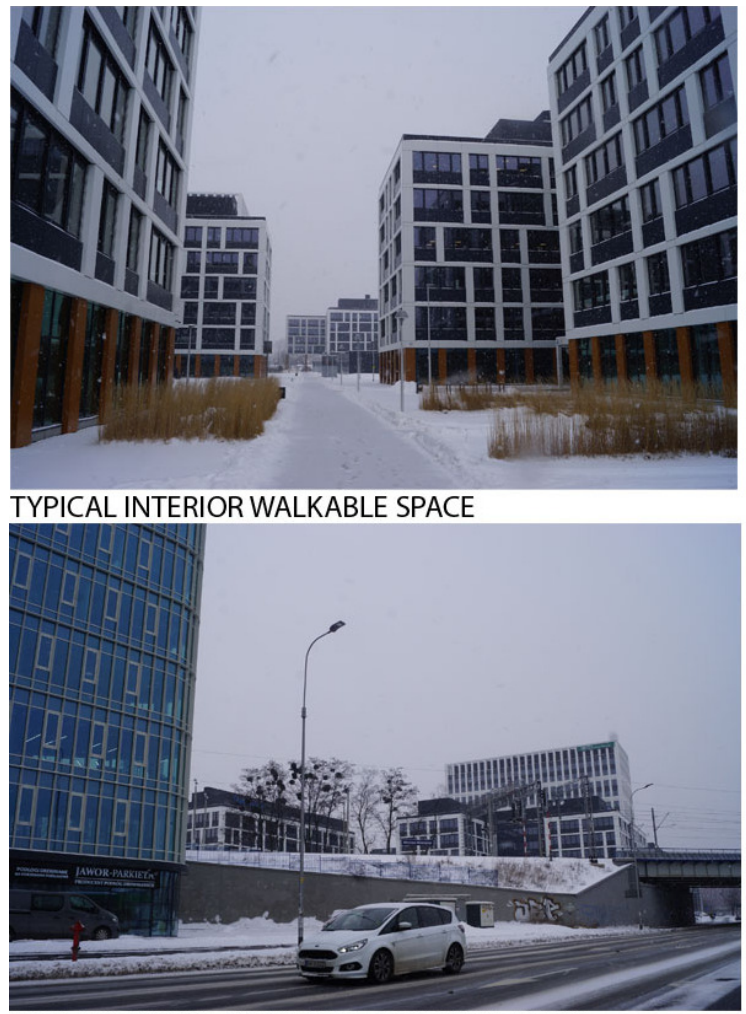

RAILTRACK AND STATION PASSING THROUGH

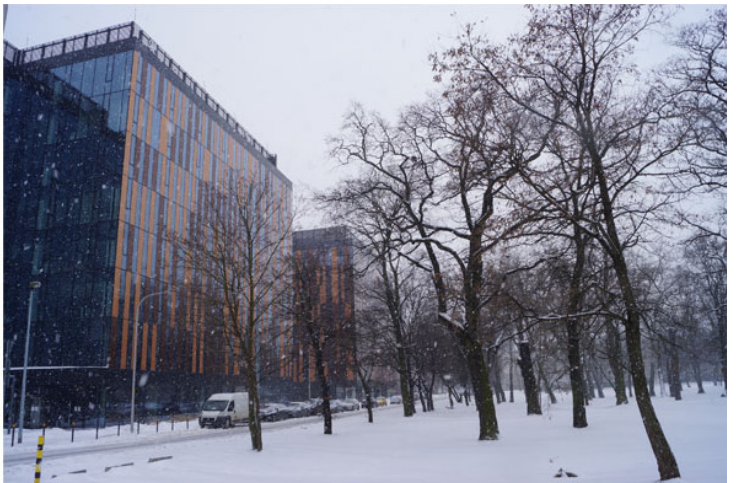

GREEN AREA CONNECTION

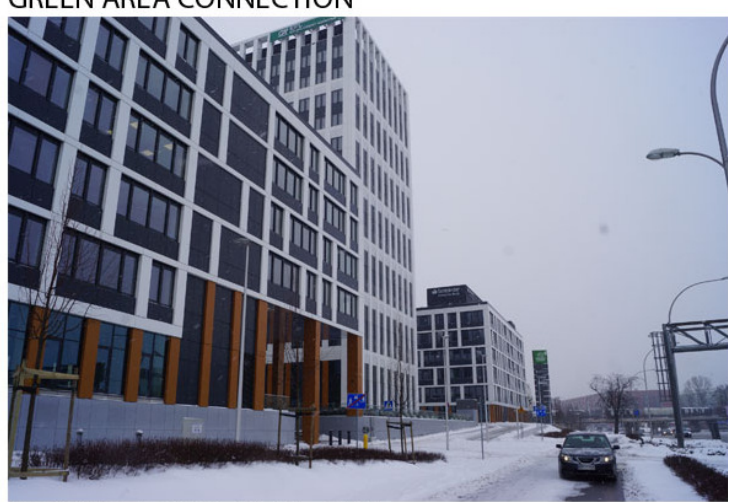

CONNECTION WITH THE CITY

Figure 6. The current state of the Wrocław study area.

although performed by large-scale developers-to a large extent are coordinated and tend to form a coherent urban structure.

\subsubsection{Social and Infrastructural Aspects of Project Implementation}

A number of the community and employee-oriented features of the urban program have been conceptualized from the very beginning as a part of the urban program for the area. These included commercial areas and leisure areas (including a large greenhouse area providing resting opportunities during the wintertime), imposing a fine-grain urban structure of the entire complex. The main part of the complex has been accompanied by several housing and other commercial and university-related functions, which brought to the area a truly diverse social image. Also, the excellent connection to the rapid regional train system allowed conceptualizing the site as a multi-use center based on the transit-oriented development scheme. As a result, a high-quality urban environment has been created, although many empty sites within the structure still call for new developments.

\section{Analysis of the Case Studies Discussed}

The critical study was based on the methodology applied to assess the quality of interactions in selected Western European office real estate broadly described in the works dealing with user perceptions of the interaction between the corporate office building and the city (Trakulwattanakit, 2021). The methodology which is applied in this research in the limited form of key variables aims to describe and compare the perception of the office-user, the local community, and the city of the CBD interactions in selected cases of Polish CBDs. After determining the appropriate indicators for variables, a cross-analysis was performed for four office real estate complexes in Poland, discussed in the previous section of this article.

Details on the criteria, variables, and factors are presented in Table 3. Following the assessments, the selected office clusters in the Polish capital and subcenters are ranked on a scale of 1 to 5 . Rating the behavioral intentions $(B)$ is based on subjective opinion to recommend CBD: 1 - strongly disagree; 2 -disagree; 3 - neutral; 4 - agree; 5 - strongly agree. Regarding the architecture/urban $(A / U)$ design of CBD complex, features such as materiality, lighting, sound, and serial scenes seen through bodily movement were assessed according to the following scale: 1 - not impressive at all; 2 - not very impressive; 3 - neutral; 4 - impressive; 5 - very impressive. Rating the subjective emotions ( $E$ ) was based on the following scale: 1 - neutral; 2 - pleasant, 3 - relaxing; 4 - pretty; 5 - exciting.

The research hypothesized that the Polish CBDs in the form of selected office clusters in major city centers are set in the triple context of the office complex premises, the city, and the community interactions 


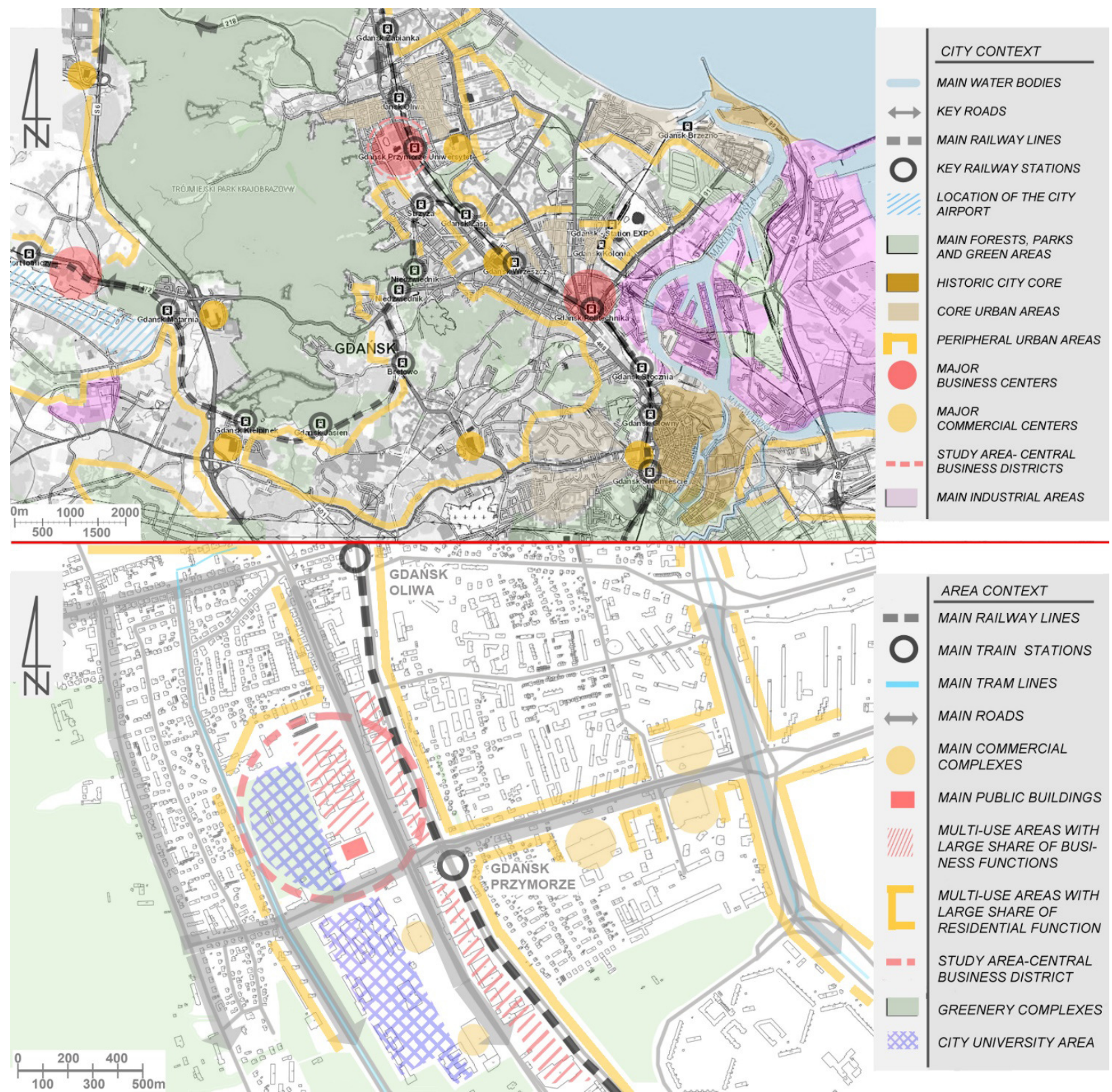

Figure 7. The urban setting of the Gdańsk case study area.

(Van de Putte, 2009). The kind of interactions within the triple context can be explored so that the impact degree on the office estate submarkets can be assessed by the designed matrix. The matrix criteria, variables, and factors can follow the survey results which originally "aimed to identify relevant variables that encourage the interaction between the corporate office building and the city from the users' perspectives and the designers' ideas" (Trakulwattanakit, 2021, p. 3). The acquired position values the degree of the interactions within the office cluster, the city, and the community triple context on the regional center's ranking. The total score of a selected sub-center places the estate complex among the others in the office submarket framework (see Table 3).

The ideal office complex should attract skilled and knowledge-intensive service sector workers (Curran, 2010; Leslie \& Hunt, 2013) who are (eco sensitively) demanding high tech on a daily basis. Therefore, the mixed-use spaces should be flexible for any combinations of functions, the workplaces open for any changes and ready for any co-creation process. The complex itself ought to be designed in (at least) BREEAM standard to cater to any desires of the privileged and welleducated creative class (Wilson \& Keil, 2008). The office development should welcome any interactions at the premises; properly addressing any ideas of co-working and/or emerging start-ups and be easily accessible and safe/secure at the same time.

The city context should improve the overall city position "by framing the municipal management within emerging urban concepts and by implementing visions associated with vigor, innovation, success, and prosperity in the public's imagination" (Hatuka et al., 2018, p. 160). Therefore, the vibrancy of the office development located 


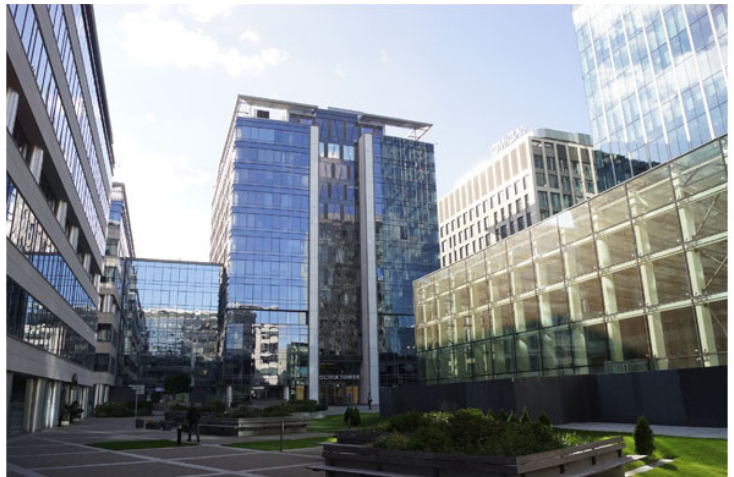

TYPICAL INTERIOR WALKABLE SPACE

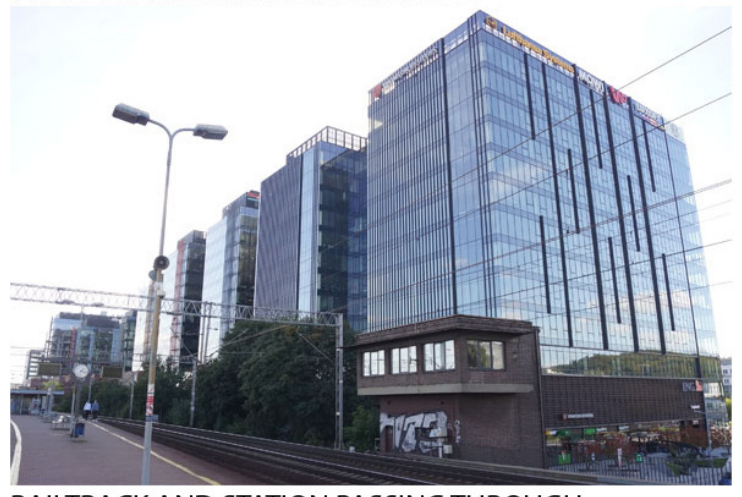

RAILTRACK AND STATION PASSING THROUGH

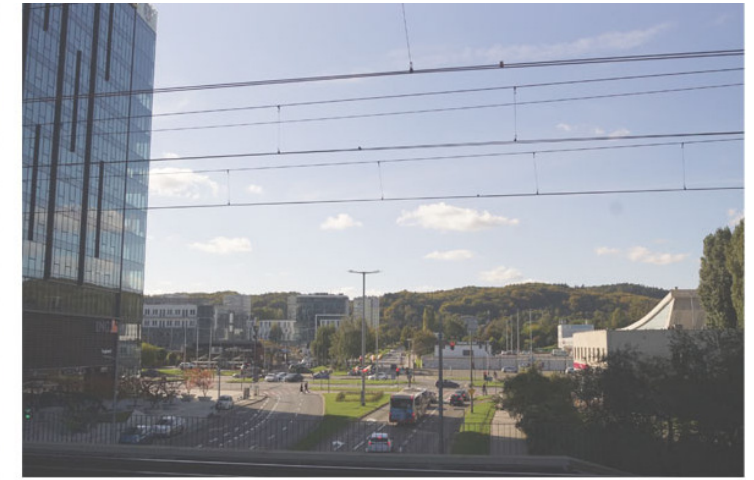

GREEN AREA CONNECTION

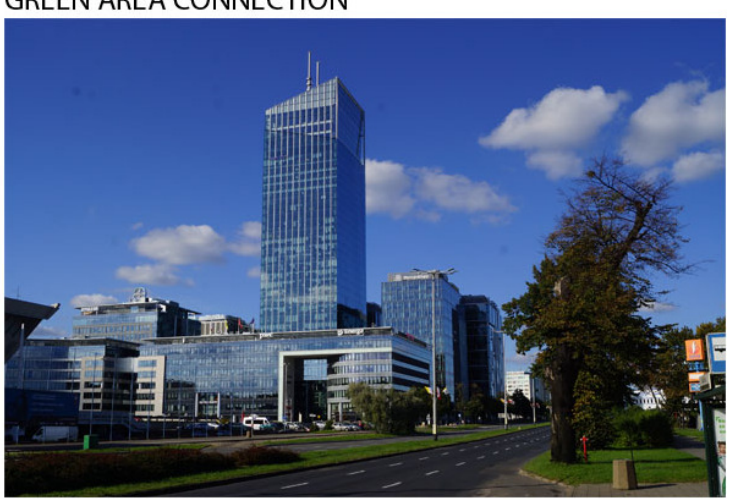

CONNECTION WITH THE CITY

Figure 8. The current state of the Gdańsk study area.

in the city structure focuses the central attention. The common anticipation is the openness of the office's public places smoothly connected with the city spaces network. Nonetheless, the importance of the development's overall harmony and aesthetic excellence from the city perspective cannot be forgotten.

The context of the community reveals the real orientation towards the needs of the residents of the area. The residents can be either perceived as users who are part of a skilled workforce resource recruiting from the upper and middle class and the consumerist-driven lower class or as the important agents in the neighbourhood development process, i.e., co-creating the public realm. The office development's design form can be motivated by the users' perception and their needs to some extent. The design form may also be devoted to either economic strength, progress, global capital, or on the contrary-strive for sustainable development and resilience by focusing on the ecological, social values, and finally on the user's needs. Therefore, the design forms show the main difficulty of an ideal office complex that should be user-oriented. The above-mentioned development of the triple context, composed of an office environment, the municipality, and the community, is usually based on theoretical insights not only of a corporation and city but also of a design company.

The assessment showed that the main weakness is the lack of interactions with a community within the triple context (office, city, and community). The scores varied from 2.29 (Warsaw) to 3.29 (Gdańsk). The absence of local community involvement activities and the unfriendly streetscape for the local community remain the main challenges for the analyzed locations. Relatively low are the scores (2.88-3.28) concerning the city context. Although Warsaw, the capital, took the lead, pollution stressors (noise and air) and lack of diversity in activities (seasonal/daily/weekly) were pointed out in all cities.

The best office cluster context (scored 4.88) is Gdańsk, well-known not only for the environmentallyfriendly development (BREEAM certificate), but also for the flexibility, business-friendly activities (co-working and startup spaces), openness, and flexibility. As far as the total value in assessment is considered, the outcomes varied from $63 \%$ in Warsaw to $74 \%$ in Gdańsk. The maintained effective rents in Gdańsk and the relatively low vacancy rate (see Table 1) indicated the uniqueness of the Gdańsk office development cluster.

\section{Discussion}

Following the assessment presented above, it is necessary to discuss the specifics of processes shaping the contemporary structures of the cases discussed. Their specifics might serve as the point of reference for processes regarding reshaping the other centrally located large-scale business centers.

First of all, in Polish realities, the formal planning procedures should be complemented by other nonformalized activities. Among these, one should mention master planning exercises developed on behalf of the local business leaders. In the case of Gdańsk, such a document helps in understanding the scope of actions to be 
Table 3. Assessment of the selected office clusters in Polish sub-centers in the triple context of interactions (matrix).

\begin{tabular}{|c|c|c|c|c|}
\hline Variables & Warsaw & Gdańsk & Cracow & Wrocław \\
\hline \multicolumn{5}{|l|}{ Office Context (ranked 1-5) } \\
\hline Easily accessible (A/U) & 5 & 5 & 5 & 4 \\
\hline Workplace and business-friendly activities (A/U) & 3 & 5 & 4 & 3 \\
\hline Safety and security $(A / U)$ & 5 & 5 & 5 & 5 \\
\hline Workplace flexibility for change $(\mathrm{A} / \mathrm{U})$ & 3 & 5 & 4 & 5 \\
\hline Operating and maintenance $(\mathrm{A} / \mathrm{U})$ & 5 & 5 & 4 & 3 \\
\hline High tech and environmentally friendly solutions $(A / U)$ & 4 & 5 & 3 & 4 \\
\hline Mixed use at ground floor (A/U) & 2 & 5 & 4 & 3 \\
\hline The flexibility of ground floor functions $(\mathrm{A} / \mathrm{U})$ & 2 & 4 & 4 & 2 \\
\hline The assessment score (average): & 3.63 & 4.88 & 4.13 & 3.63 \\
\hline \multicolumn{5}{|l|}{ City Context (ranked 1-5) } \\
\hline Opened public spaces (A/U) & 4 & 3 & 3 & 2 \\
\hline The vibrancy of the location (E) & 2 & 2 & 5 & 3 \\
\hline Aesthetics excellency $(\mathrm{E})$ & 5 & 4 & 3 & 4 \\
\hline Harmony in colors, materials, forms in the surrounding $(\mathrm{A} / \mathrm{U})$ & 4 & 3 & 3 & 4 \\
\hline Sufficient ground floor height (B) & 5 & 5 & 4 & 5 \\
\hline Diverse activities seasonal/daily/weekly (B) & 2 & 2 & 3 & 2 \\
\hline Public space without physical boundaries (A/U) & 3 & 3 & 4 & 3 \\
\hline Limited pollution (noise, air, etc.; E) & 2 & 1 & 1 & 3 \\
\hline The assessment score (average): & 3.38 & 2.88 & 3.25 & 3.25 \\
\hline \multicolumn{5}{|l|}{ Community Context (ranked 1-5) } \\
\hline Human scale provided (B) & 2 & 4 & 3 & 4 \\
\hline The scale of the street aimed at liveness in street $(\mathrm{A} / \mathrm{U})$ & 2 & 2 & 3 & 1 \\
\hline Lively plaza with attractions, i.e., water (A/U) & 3 & 3 & 2 & 2 \\
\hline Interactions with users aimed sense of belonging (E) & 2 & 3 & 4 & 3 \\
\hline Fluent connection with a transport hub (B) & 5 & 4 & 3 & 4 \\
\hline Intuitive wayfinding at the office park location (E) & 1 & 4 & 1 & 3 \\
\hline Local communities' involvement activities (B) & 1 & 3 & 3 & 2 \\
\hline The assessment score (average): & 2.29 & 3.29 & 2.71 & 2.71 \\
\hline The value (total) & 72 & 85 & 78 & 74 \\
\hline
\end{tabular}

Source: Own study based on key variables from Trakulwattanakit (2021), and the concept of rating scales based on Dai and Zheng (2021).

undertaken (Lorens et al., 2021). A lack of similar documents results in larger dispersion of the commercial and office program, which does not contribute towards the creation of the new "downtown-like" area (see the case of (racow).

Secondly, it pays to undertake cooperation with academic institutions in the process of shaping the new face of the area in question. Confronting ideas generated by both students and senior staff with the business and spatial realities of the office complexes may result in several fresh ideas that can influence the routine of the operations and the development processes undertaken by business leaders (Bach-Głowińska \& Krośnicka, 2020).

Thirdly, any important interventions cannot be made without close cooperation with the municipal and other authorities. Only joint planning and implementation efforts may result in well-structured interventions, which deal both with the site infrastructure (i.e., related to transportation) and with the transformation of the area into a truly multi-use type of district (Bach-Głowińska et al., 2020). This should also result in developing pedestrian-oriented structures, well served by the pub- lic transit (Istrate et al., 2020; Viderman \& Knierbein, 2020). Developed according to the principles of placemaking and public space design, these can serve as the new type of urban center of metropolitan importance (Carmona, 2019). Allowing for better social interactions can contribute to providing socially accepted proximity of functions and social interactions (Gil Solá \& Vilhelmson, 2019).

Finally, the site owners and developers should realize the needs of contemporary workers and the directions in reshaping the business complexes emerging from these. Only by understanding what the high-quality work environment means for contemporary workers as well as how this can be delivered may help in maintaining long-term sustainable solutions (Maric et al., 2021; Przywojska et al., 2019; Rześny-Cieplińska \& Szmelter-Jarosz, 2021).

\section{Conclusions}

At the end of the first quarter of 2020 , over 338,000 people were employed in business services in Poland $5.2 \%$ 
of employees in the sector enterprises, estimated to be responsible for $3.0-3.5 \%$ of Poland's GDP). Foreign capital in the sector of modern business services is of particular importance, preferring the major business centers in tier 1 and tier 2 cities which are located mostly in the southern part of the country. Accordingly, Polish investors open centers in tier 3 and tier 4 cities, due in particular to the interest in the IT sector over the last few years (ABSL, 2020). The Polish office business sector proved to be shock resistant, flexible, and adaptable, which the Covid-19 crisis made evident. Massive transition to remote work accelerated digital transformation without any strong effects on the business continuation. The changes were limited to adapting business strategies and reorganizing work in the major business centers in Poland. Moreover, taking into account the possible growing importance of nearshoring trends in Western Europe, Central and Eastern Europe could be the winner of the crisis.

The analysis of the Polish case studies included in this article may serve as the basis for shaping the initial conclusions regarding the future directions for the transformation of office and business complexes, especially the ones located within the city's central areas.

The first is associated with the need to understand the potential of central locations and the consequences associated with dealing with past planning and development-related decisions, i.e., transport networks and infrastructure. Also, the vicinity of these complexes is the result of past development processes and, in many cases, needs deep transformation. In recent years, municipalities have started to understand the potential associated with the transformation, but no serious actions have been planned yet.

Secondly, the developers and operators of the business complexes understand the need of transforming these structures and introducing the multi-use type of structures though, in many cases, their actions are limited only to the borders of their properties. Therefore, in case of the absence of any cooperation platform, their ideas and requests are not seen or heard, which does not spur any comprehensively shaped processes of change.

Finally, the future of these business complexes is associated with the new philosophy of work, revolving around the term "work and create." This comes from the business incubators and start-up clusters, often associated with creative districts and clusters, which should become an important point of reference for reshaping the traditional office campuses.

\section{Conflict of Interests}

The authors declare no conflict of interests.

\section{References}

ABSL. (2020). Sektor nowoczesnych usług biznesowych w Polsce [Modern business services sector in Poland]. https://absl.pl/storage/app/uploads/public/5ee/ 887/8d5/5ee8878d59858995982318.pdf

Bach-Głowińska, J., \& Krośnicka, K. (2020). Otoczenie Olivia business centre [Vicinity of the Olivia business centre]. Politechnika Gdańska.

Bach-Głowińska, J., Krośnicka, K., \& Małuj, J. (2020). Węzet multimodalny Gdańsk-Oliwa [Multimodal knot Gdańsk-Olivia]. Politechnika Gdańska.

Bagchi-Sen, S. (2001). The dynamics of industrial location: The factory, the firm and the production system. Economic Geography, 77(1), 77-79.

Barnett, C., \& Parnell, S. (2018). Spatial rationalities and the challenges for planners in the New Urban Agenda for Sustainable Development. In G. Bhan, S. Srinivas, \& V. Watson (Eds.), The Routledge companion to planning in the Global South (pp. 25-36). Routledge.

Bott, H., Grassl, G., \& Anders, S. (2019). Sustainable urban planning. Detail.

Brzezicka, J., Wiśniewski, R., \& Figurska, M. (2018). Disequilibrium in the real estate market: Evidence from Poland. Land Use Policy, 78, 515-531.

Bullivant, L. (2012). Masterplanning futures. Routledge.

Burdett, R., \& Rode, P. (Eds.). (2018). Shaping cities in an urban age. Phaidon Press.

Carmona, M. (2019). Principles for public space design, planning to do better. URBAN DESIGN International, 24(1), 47-59. https://doi.org/10.1057/s41289-0180070-3

Carta, M. (2007). Creative city. Dynamics, innovations, actions. List.

City of Kraków. (2021). Kraków local plan. https://www. bip.krakow.pl/?id=48

City of Warsaw. (2021). Warsaw local plans. http:// mapa.um.warszawa.pl/mapaApp1/mapa?service= plany_zagospodarowania

Colliers International. (2020). Polska market insights. Annual report 2020.

Culver, G. (2017). Mobility and the making of the neoliberal "creative city": The streetcar as a creative city project? Journal of Transport Geography, 58, 22-30.

Curran, J. (2010). Media and society. Bloomsbury Publishing.

Dai, T., \& Zheng, X. (2021). Understanding how multisensory spatial experience influences atmosphere, affective city image and behavioural intention. Environmental Impact Assessment Review, 89, Article 106595.

Ferguson, C. H. (2005). What's next for Google. Technology Review, 108(1), 38-46.

Firley, E., \& Grön, K. (2013). The urban masterplanning handbook. Wiley.

Florida, R. L. (2005). Cities and the creative class. Psychology Press.

Gang, W., Wang, S., Xiao, F., \& Gao, D. C. (2016). District cooling systems: Technology integration, system optimization, challenges and opportunities for applications. Renewable and Sustainable Energy Reviews, 53, 253-264. 
Gelbuda, M., Meyer, K. E., \& Delios, A. (2008). International business and institutional development in Central and Eastern Europe. Journal of International Management, 14(1), 1-11. https://doi.org/10.1016/ J.INTMAN.2007.05.011

Gil Solá, A., \& Vilhelmson, B. (2019). Negotiating proximity in sustainable urban planning: A Swedish case. Sustainability, 11(1), Article 31. https://doi.org/ $10.3390 /$ su11010031

Haas, T. (2012). Sustainable urbanism and beyond: Rethinking cities for the future. Rizzoli.

Hatuka, T., Rosen-Zvi, I., Birnhack, M., Toch, E., \& Zur, H. (2018). The political premises of contemporary urban concepts: The global city, the sustainable city, the resilient city, the creative city, and the smart city. Planning Theory \& Practice, 19(2), 160-179.

Istrate, A.-L., Bosák, V., Nováček, A., \& Slach, O. (2020). How attractive for walking are the main streets of a shrinking city? Sustainability, 12(15), Article 6060. https://doi.org/10.3390/su12156060

Karakaya, F., \& Canel, C. (1998). Underlying dimensions of business location decisions. Industrial Management \& Data Systems, 98(7), 321-329. https://doi. org/10.1108/02635579810205395

Kimelberg, S. M. (2014). Labor needs, crime, and the business location decision: A qualitative account. Community Development, 45(1), 45-59.

Kimelberg, S. M., \& Williams, E. (2013). Evaluating the importance of business location factors: The influence of facility type. Growth and Change, 44(1), 92-117.

Kołodziejczyk, B., Osiichuk, D., \& Mielcarz, P. (2021). The more, the emptier: The consequences of growing concentration in urban office space in Poland. Eastern European Economics, 59(2), 171-197. https://doi. org/10.1080/00128775.2020.1870408

Landry, C. (2008). The creative city: A toolkit for urban innovators ( 2 nd ed.). Earthscan.

Leslie, D., \& Hunt, M. (2013). Securing the neoliberal city: Discourses of creativity and priority neighborhoods in Toronto, Canada. Urban Geography, 34(8), 1171-1192.

Lorens, P., Obracht-Prondzyńska, H., \& Breś, J. (2021). Nowa Oliwa masterplan [New Oliwa masterplan]. Politechnika Gdańska.

Luthans, F., Patrick, R. R., \& Luthans, B. C. (1995). Doing business in Central and Eastern Europe: Political, economic, and cultural diversity. Business Horizons, 38(5), 9-16. https://doi.org/10.1016/00076813(95)90031-4

Maric, J., Aleksandra, D., Antonic, B., Furundzic, D., \& Parezanin, V. (2021). The effects of open space on reducing workplace stress: Case study of business park in the post-socialist urban setting. Sustainability, 13(1), Article 336. https://doi.org/10.3390/ su13010336

McCartney, J. (2012). Short and long-run rent adjustment in the Dublin office market. Journal of Property Research, 29(3), 201-226.
Meijer, M., Dubbeling, M., \& Marelis, A. (Eds.). (2010). Sustainable urban design. Blauwdruk.

Morawiecki, M. (2021). Rynek nieruchomości biurowych: Poczqutek trudnych czasów? [Office real estate market: Beginning of tough times?]. Department of Economic Analysis of the PKO Bank of Poland. https://www.pkobp.pl/media_files/e11cef77-493e4d6b-b046-ef96e197e4fe.pdf

Murphy, R. E. (2017). The central business district: $A$ study in urban geography. Routledge.

Office of the Capital City of Warsaw. (2018). Spatial policy of the capital city of Warsaw. http://www. architektura.um.warszawa.pl/studium

Ossowicz, T. (2019). Urbanistyka operacyjna. Zarys Teorii [Operational city planning. The outline of a theory]. Oficyna Wydawnicza Politechniki Wrocławskiej.

Parteka, T. (2008). Europejskie wyzwania spójności przestrzeni [European challenges of space cohesion]. Wydawnictwo Politechniki Gdańskiej.

Patacchini, E., Picard, P. M., \& Zenou, Y. (2015). Urban social structure, social capital and spatial proximity (CEPR Discussion Paper No. DP10501). Centre for Economic Policy Research.

Polese, M., \& Chapain, C. (2000). Are central business districts (CBDs) really declining? An analysis for U.S. and Canadian urban areas. University of Quebec.

Polish Office Market. (2019). Raport. Powierzchnie biurowe w Polsce 2019 [Report: Office spaces in Poland 2019]. AXI IMMO. https://www.axiimmo. com/raporty-i-publikacje/raport-powierzchniebiurowe-w-polsce-2019

Polish Office Research Forum. (2017). Office 2017, Guide New Warsaw office zones. Colliers International. http://bpcc.org.pl/uploads/ckeditor/attachments/ 12464/Raport_Guide_New_Warsaw_Office_Zones. pdf

Portal of the City of Gdańsk. (2021). Gdańsk development plan. https://www.gdansk.pl/studium/ obowiazujace-studium-suikzp,a,113625

Przywojska, J., Podgórniak-Krzykacz, A., \& Wiktorowicz, J. (2019). Perceptions of priority policy areas and interventions for urban sustainability in Polish municipalities: Can Polish cities become smart, inclusive and green? Sustainability, 11(14), 3962. https://doi.org/ $10.3390 /$ su11143962

Public Information Bulletin of the City of Kraków. (2014). Krakow development strategy. https://www. bip.krakow.pl/?id=48

Rudlin, D., \& Hemani, S. (2019). Climax city: Masterplanning and the complexity of urban growth. Routledge.

Rześny-Cieplińska, J., \& Szmelter-Jarosz, A. (2021). Stakeholders' analysis of environmental sustainability in urban logistics: A case study of Tricity, Poland. Energies, 14(5), Article 1274. https://doi.org/10.3390/ en 14051274

Säynäjoki, E.-S., Inkeri, V., Heinonen, J., \& Junnila, S. (2014). How central business district developments facilitate environmental sustainability: A multiple 
case study in Finland. Cities, 41, 101-113. https:// doi.org/10.1016/j.cities.2014.05.010

Smętkowski, M., Celińska-Janowicz, D., \& Wojnar, K. (2019). Nowe przestrzenie gospodarcze metropoliiOd postmetropolii do metropolii mozaikowej? [New economic spaces of metropolises-From post-metropolises to mosaic metropolises?]. Studia Regionalne i Lokalne, 4(78), 28-53.

Smętkowski, M., Celińska-Janowicz, D., \& Wojnar, K. (2021). Location patterns of advanced producer service firms in Warsaw: A tale of agglomeration in the era of creativity. Cities, 108, Article 102937.

Stangel, M. (2013). Kształtowanie współczesnych obszarów miejskich w kontekście zrównoważonego rozwoju [Shaping contemporary urban areas in the context of sustainable development]. Wydawnictwo Politechniki Śląskiej.

Statistics Poland. (2021). Registered unemployed persons and unemployment rate. As at the end of January 2021. https://stat.gov.pl/en/topics/labour-market/ registered-unemployment/registered-unemployedpersons-and-unemployment-rate-as-at-the-end-ofjanuary-2021,1,102.html

Tapsuwan, S., Mathot, C., Walker, I., \& Barnett, G. (2018). Preferences for sustainable, livable and resilient neighbourhoods and homes: A case of Canberra, Australia. Sustainable Cities and Society, 37, 133-145.

Trakulwattanakit, P. (2021). Corporations and cities: Designer's intentions and user perceptions of the interaction between corporate office building and the city [Master's thesis, Delft University of Technology]. TU Delft Repository. https://repository.tudelft.nl/ islandora/object/uuid:d35f038b-2ac2-4297-9c4c$6 \mathrm{bc1c8ce} 40 \mathrm{a} 4$ ?collection=education

Van de Putte, H. J. M. (2009). Corporations and cities. Real Estate Magazine, 12(63), 40-45.

Viderman, T., \& Knierbein, S. (2020). Affective urbanism: Towards inclusive design praxis. URBAN DESIGN International, 25, 53-62. https://doi.org/10.1057/ s41289-019-00105-6

Wilson, D., \& Keil, R. (2008). The real creative class. Social \& Cultural Geography, 9(8), 841-847.

Wrocław Spatial Information System. (2021a). Studium uwarunkowań I kierunków zagospodarowania przestrzennego Wrocławia [Study of the conditions and directions of spatial development]. https://gis. um.wroc.pl/imap/?gpmap=Studium2018\&locale=en

Wrocław Spatial Information System. (2021b). Plany miejscowe [Local spatial development plans]. https:// gis.um.wroc.pl/imap/?gpmap=gp7\&locale=en

\section{About the Authors}

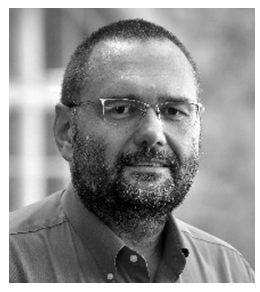

Piotr Lorens (PhD) is an urban planner and the Gdańsk City Architect since 2021. He is also a professor in urban design and development since 2007, and head of the Department of Urban Design and Regional Planning at the Faculty of Architecture of Gdańsk University of Technology. His professional interests include urban planning and regeneration processes, with a special focus on waterfront areas and public spaces.

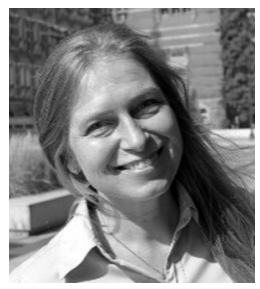

Joanna Bach-Głowińska (PhD) is an urban planner and the winner of the 2013 national competition for the best doctoral dissertation on local government and decentralization issues. She continued her research at the Glasgow School of Art for over two years and has done so at the Architecture Faculty of Gdańsk Tech since 2014. From 2000 to 2017, she worked as a city planner for Gdańsk City, where her urban studies comparing Gdańsk to Dublin (2010) and Glasgow (2014-2015) inspired the foundation of Urban Initiatives Lab in 2015. Since 2018, she has been coordinating the Polish consortium in the international Sustainable Urbanization Global Initiative (SUGI) project CRUNCH.

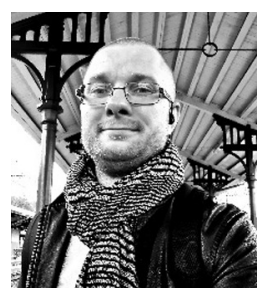

Michał Habier (MSc) is a PhD candidate in architecture. He is working as a legal advisor in a private legal practice and is cooperating with municipal companies and local government authorities. He is also a teaching assistant at the Department of Urban Design and Regional Planning of the Faculty of Architecture of Gdańsk University of Technology.

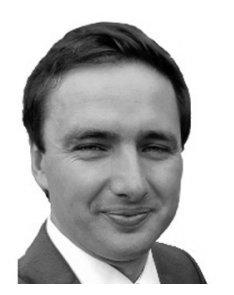

Paweł Roger Rzepecki (MSc) is an architect and a PhD student at the Technical University of Wrocław and presently at Gdańsk University of Technology. He also works as a freelance practitioner in projects involving housing, hospitals, multistory buildings, and marine engineering. His main research interests are sustainability in modern cities, motion in urban space, and the relation between architecture and urban areas of people flow. 